\title{
Putting a face on forest history in Canada
}

\author{
by Peter M. Morley ${ }^{1}$
}

\begin{abstract}
The Forest History Society, established in St.Paul in 1946 has been continuously broadening the base and scope of its activities. During the past five years, much greater emphasis has been placed on Canadian involvement in the Society, culminating in the appointment of a 'Committee on Canada' in 1990. The findings of the Committee and details of one proposed project are outlined.
\end{abstract}

\section{Résumé}

La Forest History Society, crée à St-Paul en 1946 n'a jamais cessé d'élargir le cadre de ses activités. Au cours des cinq dernières années, on a mis beaucoup plus d'accent sur la participation canadienne aux activités de la Society, ce qui s'est traduit par la création d'un «Committee on Canada» en 1990. On décrit les résultats des travaux du comité et présente en détail un de ses projets.
Everyone has a stake in the broader public understanding of our significant forest heritage. This has been, from the beginning, one of the main tenets of the Forest History Society. Its founders believed that only a true understanding of the past could help us determine its impact on the future.

During World War II, Rodney C. Loehr served as historical officer for the Allied Joint Chiefs of Staff. On his return in 1946, to his former position on the history faculty of the University of Minnesota at St.Paul, he was appointed as director of the Forest History Society. It was then known as the Forest Products History Foundation, and was a branch of the Minnesota Historical Society. Loehr was supposed to work halftime for the university, halftime for the Society. However in a recent interview he recalls "Both were fulltime jobs"'.

Loehr received support and basic funding from Theodore Blegen, dean of the university graduate school and from F.K. Weyerhaeuser, but it was really his job to define the limits of his subject. He established an interim definition of forest history as events that began in the forest but stopped at the sawmill. Focussing on logging and transportation methods to the mill, he gave top priority to generating forest history literature that would become 'building blocks' for a national history.

Since 1950, when Loehr retired as director, the Society's interests have become much more extensively based. The definition of "forest history" has been broadened to include forest resource professions, agencies and institutions, and more recently, includes the conservation movement as well. Its scope is now North American and beyond, and its publications include a quarterly journal, Forest and Conservation History and a newsletter, The Cruiser, which reports on FHS programs and the activities of staff and members. It is now located near the campus of Duke University, which incidentally has a very active program of Canadian Studies. The present Executive Director is Harold K. (Pete) Steen who has served in this capacity since 1978.

The Library Program of the Forest History Society is one of which it can be proud. The Society maintains a bibliography of fourteen thousand citations to the secondary literature and has identified six thousand groups of records held by four hundred archival institutions. These holdings are located in the United States and Canada, and provide a rich

'Peter M. Morley Associates, 778 Avenue Road, Toronto, Ontario. resource for all those interested in forest history. The Society has also contributed greatly to the continent's archives by locating and facilitating the deposit of literally tons of records and by recording oral interviews with over two hundred leaders in industry and the professions. Its Research Program has yielded sixteen books.

While over the earlier years of its existence, the Society had always maintained an interest in Canadian forest history and membership, it was only in the past five years that this interest has come into the main stream. A symposium held in Vancouver in October 1986 coincided with that city's centennial celebrations, Expo 86. One of the principal speakers at that symposium was Herb Winer whom many Canadian foresters will recall was at one time based at Pointe Claire, Quebec. He was employed at that time by the Woodlands Section, PPRIC, the forerunner of the Forest Engineering Institute of Canada. Winer became manager of Mead Corporation's Woodlands Resource Program and subsequently was elected President of the Forest History Society.

The Vancouver meeting entitled "Forests and the 49th Parallel"' dealt with such topics as "Entrepreneurs, Forests, and Conservation", "Resource Management in the Great Lakes Basin", "'Selling Eastern Canadian wood in the late 19th Century', and "'The Wood Trade in the Pacific Northwest" all areas where Canadian and U.S. forest histories have been intertwined. Canadian speakers, many of whom have since taken an active part in the operation of the Society included Graeme Wynn of U.B.C., Paul Bienvenu of Howard Bienvenu Company, Peter Gillis of the National Archives, Ottawa and Vern Wellburn of FERIC Vancouver.

Subsequently, Society meetings have been held in Canada at Ottawa in April 1989 and in Montreal in August 1990, this latter coinciding with the IUFRO meeting held there. At Ottawa, Peter Gillis organized a one-day program which featured presentations on the square timber trade on the Ottawa River, also a well researched paper by Clarence Coons of Ontario MNR dealing with some of the early logging machinery developed by the pioneers. At Montreal, a field trip was organized by Jean Berard for the delegates to see a replica of early maple sugaring operations. It was at this meeting that the Society directors decided that a 'Committee on Canada' should be formed to determine Canadian priorities and objectives within the Society.

This group whose chairman is Pit Desjardins, formerly of Weldwood of Canada included among others, Jean Berard; 


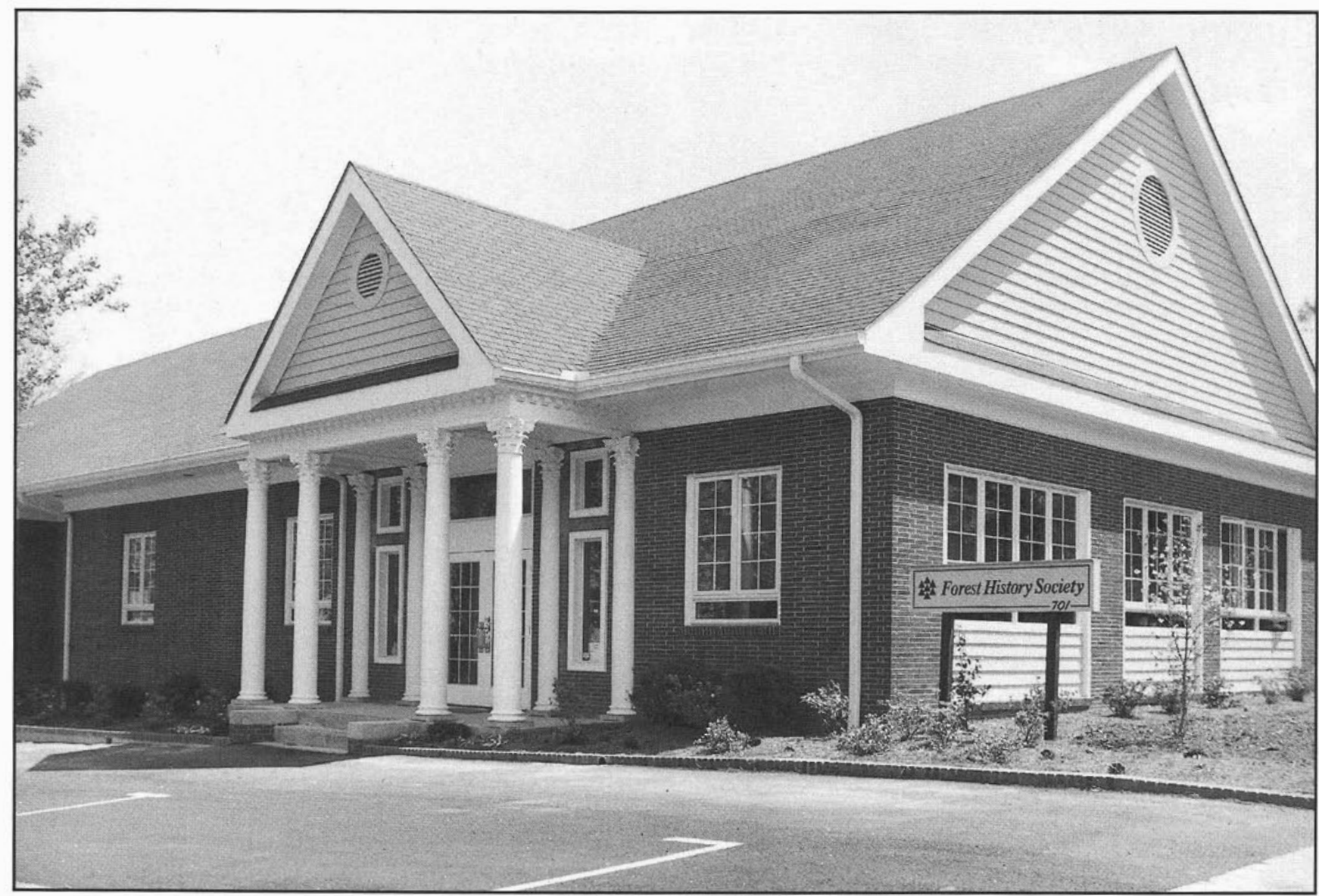

Figure 1. The Forest History Society, Durham, N.C. April 29, 1988.

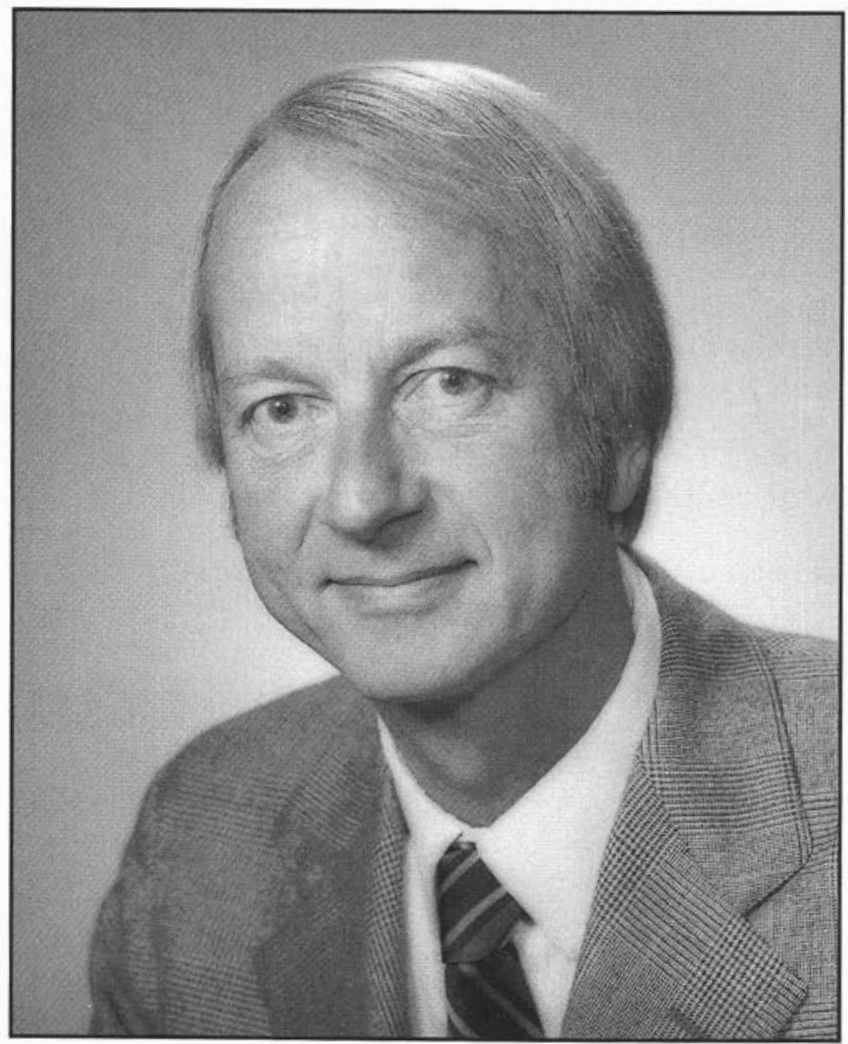

Figure 2. Harold K. "Pete" Steen, Executive Director, F.H.S.
Paul Bienvenu; Peter Murphy, Professor of Forest Management, University of Alberta; Les Reed, Professor of Forest Policy Research, U.B.C.; Graeme Wynn; and Adam Zimmerman of Noranda Forest. The first meeting of the Committee was held in Toronto in the fall of 1990. Their mandate was to examine the Society's programs and report back on how well they met Canada's forest history needs.

Surprisingly, for such a diverse group, there was a large degree of consensus as to what was, and was not needed. The following summarizes the main points made by the Committee:

(a) There was no advantage seen in establishing a Canadian office for the Forest History Society; this would only result in a duplication of administrative costs and would be inefficient.

(b) A regional rather than a national approach to Canadian forest and conservation history was considered to be more appropriate.

(c) Present FHS meetings and conferences should be continued to encourage the exchange of ideas. Also, oral history workshops to train interviewers should be arranged. Such was considered to be the most cost-effective way to field the number of interviewers needed to capture the experiences of those still living; individuals who can provide first-hand accounts of material changes in Canadian forest issues and programs.

(d) Priority should be given to establishing a publication series of pamphlet-length, objective syntheses of key issues. 
(e) Liaison should be established with the Canadian Pulp \& Paper Association. The Association has an active public school education program.

An earlier initiative undertaken by Peter Murphy that will probably get Forest History Society support, is worthy of mention. The Dominion Forestry Service now Forestry Canada, was established in 1899. Many photographs were taken of the Service's activities and by the 1950 s the central collection had grown to about 40,000 pictures. Many of these pictures were dispersed among the regional units as they became established; undoubtedly many of these were destroyed as a result of housecleaning etc. However, a sufficient number were saved through the efforts of some far-sighted individuals to give us an engrossing transect of forestry activities and achievements over the fifty some years during which they were collected.

Murphy is proposing the inventorying of all known Dominion Forestry photographs across the country. The data would be compiled on a computer data base enabling key word searches for example, by year, geographic location, etc. An actual collection of prints, original or copies would be assembled and made available for broader reference by laser disc or computer scanning. Present indications are that a collection of six to seven thousand prints could be assembled up to the 1930 date of the Transfer of Resources, and perhaps about the same number afterwards.

Clearly there is much to be done if we are going to draw effectively on the experience of the past for a better understanding of the future. A real challenge is thus presented to the forestry profession in Canada. If you have any ideas or suggestions on the subject, why not write directly to Pete Steen, Executive Director, Forest History Society, 701 Vickers Drive, Durham, North Carolina 27701 USA. Better still, please give serious consideration to taking out a membership in the Forest History Society. I can assure you that you will find the money well spent.

\title{
The Nuts and Bolts of Scholarly Publishing: Workshop for Editors of Canadian Scientific and Engineering Journals
}

\author{
September 25-27, 1991 \\ Lodge at Kananaskis \\ Kananaskis Village, Alberta \\ Organized and Sponsored by
}

National Advisory Board on Scientific and Engineering Publications

National Research Council of Canada

Natural Sciences and Engineering Research Council of Canada

Information:

Mike Boroczki

Research Journals

National Research Council of Canada

Bldg. M-55, Montreal Road

Ottawa, Ont., Canada K1A OR6

Telephone: (613) 993-9108

FAX: (613) 952-7656 